\title{
Governance Autonomy to Improve Service Quality with Dynamic Linkage of Civil Society Organizations in Development Policy
}

\author{
Sri Hartini Jatmikowati ${ }^{1}$, Chandra Dinata ${ }^{2}$, Bambang Noorsetya ${ }^{3}$ \\ \{ sri.hartini@unmer.ac.id ${ }^{1}$, chand.dinata@unmer.ac.id ${ }^{2}$,dhiela_028@ymail.com ${ }^{3}$ \} \\ Dept. of Public Administration, University of Merdeka Malang, Indonesia ${ }^{1}$ \\ Dept. of Public Administration, University of Merdeka Malang, Indonesia ${ }^{2}$ \\ Dept. of Public Administration, University of Merdeka Malang, Indonesia ${ }^{3}$
}

\begin{abstract}
This article discusses the involvement of civil society organizations in the regions in implementing development policies, especially in promoting the mission of local governments to strengthen the economic resilience of rural communities. The civil society knot through the movement of civil society organizations in the regions which are managed autonomously by the district government by utilizing the social capital they have is able to move the coffers of the economy independently. The existence of civil society organizations reinforces governance based on multi-actor collaboration to create community welfare, especially rural communities.
\end{abstract}

Keywords: Collaborative; Governance; Development; Decentralization.

\section{Introduction}

Industrial democracy underwent a change in the goals and methods of government. There are several basic elements that cause this change to occur, including an increase in deficit, economic stagnation, and disappointment with the prosperity solution presented by developed developing countries. This change raises questions about the scope and nature of public administration, both as a profession and as a scientific discipline. During the $20^{\text {th }}$ century, public administration focused on a bureaucratic, hierarchical, and accountability approach. Nonetheless, theoretical hegemony in public administration collapsed in the 1950s by Waldo, Simon and others so as to experience a dichotomous setback from political administration as a core discipline that cannot change the nature of government institutions. The collapse of the orthodox theory which emphasizes that the bureaucracy with central policy jurisdiction is no longer outside or above politics but remains a central supplier of public goods and services and still defines what administrative theory wants to explain.

The $21^{\text {st }}$ century with the flow of globalization in all lines of life in society and the state makes knowledge about public administration adapt to these changing environments. Since the fourth paradigm of public administration, various metamorphosed theories have emerged to strengthen public administration with a governance approach, as an effort to improve administrative performance individually, in groups and organizations in achieving goals effectively and efficiently [1]. The idea of governance that was born from public management 
theories, so that the debate about the implementation of government affairs for the public interest became the main domain for the birth of governance theory [2]. Governance in the context of public administration is used as a new vehicle for separating politics and administration as the first paradigm of public administration developed.

In principle, governance theory embodies thoughts about the roles of the state to its citizens. Therefore, this theory tries to expand the reach of the state (government) in providing good services to its citizens by opening the tap for the participation of other sectors outside the government, namely private and civil society. Through the addition of actors in the implementation of service functions that should be provided by the government, it is hoped that it will be able to shorten the reach of the community to public services provided by the government. The concept of governance can be implemented at the institutional, organizational and technical levels [2]. The institutional level lies in the rules or norms that apply, then at the organizational level it lies in the managerial level of an organization, and the last one is the technical level that refers to conditions or the environment that will affect the functioning of institutions and organizations.

It should be realized that in implementing the concept of governance, the existence of groups of civil society and groups of capital owners (private) in governance will provide new space for public services so as to strengthen the position of the state in distributing its authority, so that the results achieved are excellent service to public services. citizen. This change is in principle a means of administrative reform [1] which is comprehensive in governance so that accountability in carrying out service improvements to the community with an entrepreneurial approach can be achieved legally [3]. This change requires a deal with the existing theory of public administration, because this is the basic concept of the discipline of public administration to create a government that is professional and with high integrity so that it is able to provide excellent service to the community and democratic governance so that it is able to face the challenges of the $21^{\text {st }}$ century through good governance.

The shift and development of governance starts from good governance which wants a government to be well organized in its management so that a legal system appears in running it to produce good services to the community, this process is better known as public sector reform [4] based on global geopolitical changes that emphasize people as citizens [5] so that policies made by the government to solve social problems can be carried out with development policies that are based on democracy so as to open up space for civil society participation [6], [7], [8].

Governance practice continues to enter its development when a theory about sound governance emerges, which is the concept of maximally involving citizens in governance [9] so that the emphasis on sound governance is governance based on local values by taking into account global aspects. The historical wheel of development continues to rotate, along with the increasing needs and desires of citizens, the concept of governance continues to evolve to make the government a friendly and inclusive actor in providing services, therefore adaptive principles are attached to the concept of governance so that it becomes adaptive governance [10] to create internal changes driven by global demands [11], [12], [13]. The administrative environment contributes greatly to the fast or slow of governance reforms, therefore globalization which places technology as a form of progress in social interaction shifts the administrative paradigm by strengthening governance with information technology, this change process is shown by smart governance [14], [15], [16].

Democracy is used as a medium to distribute welfare evenly to citizens who adhere to the concept of social equity in applying the new public administration [2] to strengthen human relations [17] in government, so that in the basic context of public administration reform it returns to its foundation of thought, namely building a strategy for providing services to the 
community optimally by prioritizing the needs of citizens [18]. Therefore collaborative governance is used as a mainstay in resource management to be utilized by the public which is facilitated by the government by collaborating with multi actors in realizing equity and prosperity [19], [20], [21], [22], [23].

The context of multi-stakeholder involvement in distributing government roles to provide services to society which leads to equity and welfare, knot civil society through civil society organizations as partners [20] to implement the development policy strategy proclaimed by the government [24]. Therefore, this article discusses the involvement of civil society organizations in strengthening the economic resilience of rural communities at the regional government level autonomously proclaimed by local governments.

\section{Collaborative Governance-Based Rural Development Policy Conceptualization}

Village, is known for its agricultural characteristics [25], [26] so that capital for rural economic development is needed linkage or stakeholders as the main key to the success of policy implementation as a system (Duit et al., 2010) because with the linkage, multi-actor synchronization occurs [27] villages and between villages to try to support the rural economic system in an agrarian-based ecosystem [28]. Several conditions, the emergence of a spacial environment so that in carrying out the process of synchronization the objectives are still limited and segregated [29]. In this condition, it clearly shows that the existence of rural communities is in a pattern of segregation or dichotomy between urban and rural areas. This condition causes the agricultural sector to begin to be abandoned by rural people for urbanization, leaving agricultural lands, which results in reduced agricultural output which affects the economic system of rural communities, and poverty results [30], [31]. The linkage needed to accommodate various policies for rural economic resilience is used as an effort by the government to reduce poverty in rural areas [32]. The conceptualization in the linkage and collaboration of rural economic resilience is clear in the following figure: 


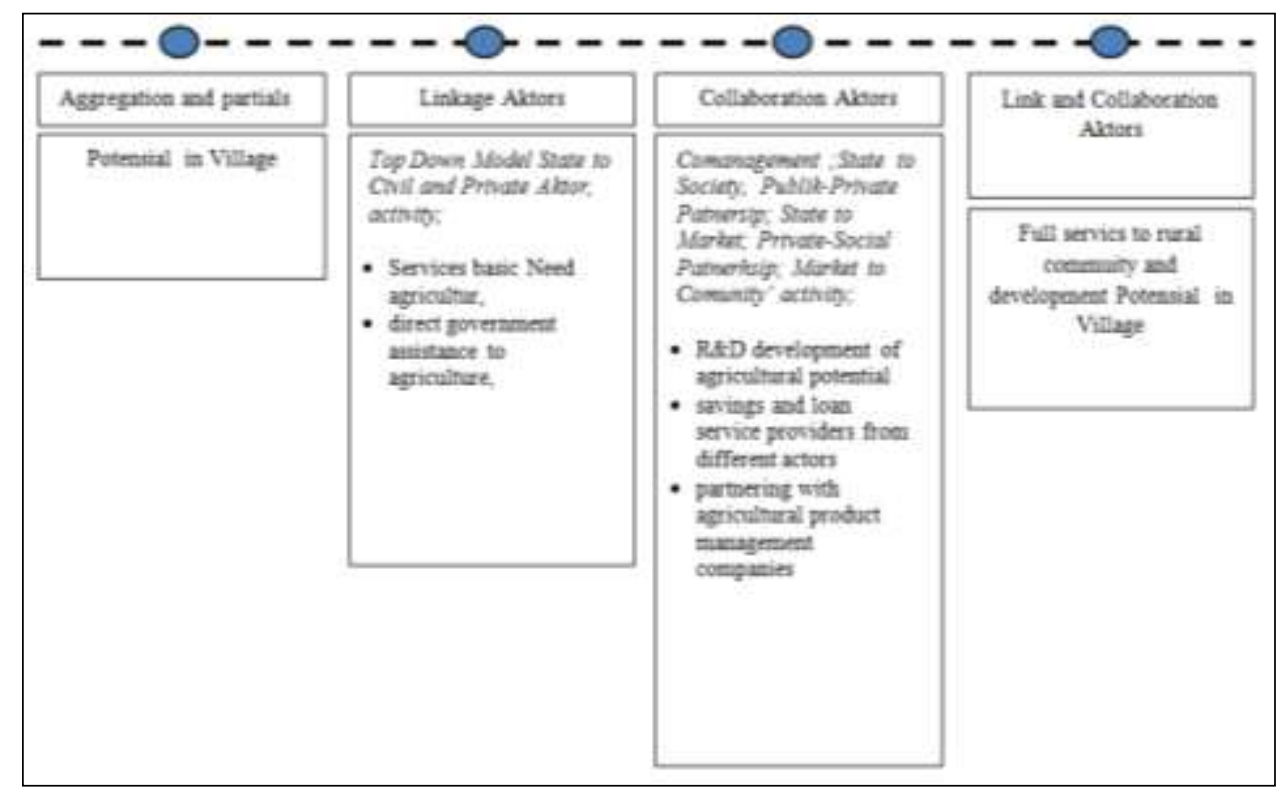

Fig. 1. Dynamic Linkage Governance of Collaboration

Seeing the pattern of linkage collaboration actors [33] in an effort to economic resilience in rural communities is defined as a dynamic condition of the nation's economy which contains tenacity and resilience to maintain social capital as the glue of togetherness so that it contains the ability to develop all resources together as the principle of equality. So that national strength in facing and overcoming all threats, disturbances, obstacles and challenges that come from outside and from within, both directly and indirectly in order to ensure the economic survival of the nation and the State can be resolved properly.

The realization of economic resilience is reflected in the condition of the nation's economy, which contains the ability to maintain healthy and dynamic economic stability as well as the ability to create national economic independence with high competitiveness and create a just and equitable prosperity for the people. Thus, economic development is directed towards stable economic resilience through the creation of a healthy business climate and the use of science and technology, the availability of goods and services, the preservation of environmental functions and increasing competitiveness within the scope of global competition.

\section{Rural Economic Resilience and Development Policy in Autonomous Regions}

In Indonesia, economic resilience can be seen from the perspective of the human development index which includes indicators of adequacy of education, health and income levels. Experts explain that the economic resilience of the community can be seen from the affordability of access to adequate food individually and in groups so that they can maintain their daily needs, both physically and economically [34], [35], [36] according to the portion of the job. 
Malang Regency in poverty alleviation efforts are still carried out massively. The pattern carried out in this program is in the hands of the regional government and village government, in line with the regional autonomy system as stated in Law No. 23 of 2014 and Government Regulation No. 06 of 2020 concerning Villages ${ }^{1}$. Therefore, the focus on the rural economic resilience index is a development design oriented towards poverty alleviation and eliminating social inequality. Thus, the problems found as a form of economic resilience for rural communities include four things, namely; First, the low level or standard of living of agricultural households in general; Second, the lack of resilience or vulnerability of agricultural household economies; Third, the disparity is quite wide for the agricultural household economy between regions with different social models; and Fourth, differences in the dimensions of economic resilience of agricultural households between regions (rural-urban). Empirically, the economic resilience of rural communities is basically family-based, handled by regional governments autonomously and in cooperation as a basis for multi-actor collaboration to improve the economic quality of the community by optimizing the resources owned by local institutions so that there is a distribution of roles.

Economic development is aimed at economic resilience by creating an appropriate business climate, utilizing science and technology, providing goods and services, maintaining environmental functions, and increasing competitiveness. Therefore, the policy to realize economic resilience is carried out through a village potential management program in the tourism sector where the potential development process aims to open jobs with a triple helix development pattern [37] and in practice it is still top down, while the hope is that innovation will become the domain and responsibility of the industrial world, develop innovation in the academic realm and be interacted with by the government, especially local governments. Thus, the application of innovation run by the local government autonomously rests on local voice, vocal choice and local wisdome as a form of community consensus in building villages [38].

\section{Dynamic Linkage of Civil Society Organizations in Creating Good Collaborative Governance to Improve Economic Resilience of Rural Communities}

Economic weakness is a problem that is not only resolved independently, but with a multidimensional approach, as is limited human access to exploration of human resource potential through education. Weaknesses in the level and level of education cause the inability to apply technology so that the main problems faced in promoting economic resilience are the factors that affect the marketing of products. Technological developments cannot be used to access markets, so that most rural communities who make their living as farmers use the services of middlemen who culturally can exploit and at the same time act as a bridge connecting the market when marketing their products. The relationship between middlemen and farmers and agricultural products has a negative impact, namely price monopoly because market communication is imperfect, this indicates that there are many transactional prices in the market system but do not involve producers directly.

Rural communities who always live side by side with nature, and even depend on nature for their lives, are certainly a social entity that has developed from generation to generation with

\footnotetext{
${ }^{1}$ Article 18 village authority includes authority in the field of running village governance, implementing village development, fostering village communities, and empowering village communities based on community initiatives, rights of origin, and village customs.
} 
a strong social capital package so that the social institutions of rural communities are very strong. This capital, if viewed from the point of view of developing economic resources which is managed properly and facilitated by the government in an autonomous manner, can raise the standard of life of rural communities. Coupled with building multi actor collaboration in the management of all resources, including social resources, which serve as the glue for communalism.

Civil society organizations that continue to experience significant development because they follow the dynamics of democratic development in one nation [39], have become one of the actors who always encourage social changes by upholding local values so that they can give color in every development policy process. which was proclaimed by the government. In the era of autonomy, the interaction built by civil society organizations in their involvement in the public policy process (formulation-implementation-evaluation) so that institutionally, civil society organizations become the driving force for the economic empowerment of rural communities. The presence of civil society organizations in implementing development policies can strengthen policy objectives so that the powerlessness of rural communities in controlling access to information for economic strengthening can be facilitated, so that the gap in life between rural and urban communities can be eliminated through the active role of civil society organizations as collaborative actors in the development of autonomous regions.

\section{Conclution}

Economic resilience programs, which are also part of the welfare policy and reduce poverty, are programs that are not only subsidized, but must empower family members of the bafer policy. So far, this has been carried out by improving the economy of the spicy community which is nota bene based on agrarianism which focuses on the success of the program administratively. Likewise, from the beneficiary side, the use of stimulation through empowerment is still mostly used for cooperative activities, resulting in dependency.

The involvement of civil society organizations in development policies is not limited to formal interactions across actors, but a total multi-perspective interaction in dealing with social and economic problems in autonomous areas. The dynamics of the development of theoretical governance can be seen from the scientific development of public administration, so that the presence of civil society organizations is not a complement to democracy but becomes a reinforcement of local democracy with values of struggle based on local wisdom. Thus, the existence of these civil society groups becomes a color in the innovation of governance in today's era.

\section{References}

[1] Caiden, G. E. (2017). Administrative reform. In Administrative Reform. https://doi.org/10.4324/9781315083032

[2] Frederickson, H. G., Smith, K. B., Larimer, C. W., \& Licari, M. J. (2018). The public administration theory primer, third edition. In The Public Administration Theory Primer, Third Edition. https://doi.org/10.4324/9780429494369

[3] Burgi, M. (2020). Public Administration and Law. In European Perspectives for Public Administration. https://doi.org/10.2307/j.ctvv417th.12 
[4] Rhodes, R. A. W. (2007). Understanding governance: Ten years on. Organization Studies. https://doi.org/10.1177/0170840607076586

[5] Rosenau, J. N. (2009). Governance, order, and change in world politics. In Governance without Government. https://doi.org/10.1017/cbo9780511521775.003

[6] Hyden, G. (1997). Civil society, social capital, and development: Dissection of a complex discourse. Studies in Comparative International Development. https://doi.org/10.1007/BF02696304

[7] Hyden, G., Court, J., \& Mease, K. (2003). the Bureaucracy and Governance in 16 Developing Countries. World.

[8] Lange, P., Driessen, P. P. J., Sauer, A., Bornemann, B., \& Burger, P. (2013). Governing Towards Sustainability-Conceptualizing Modes of Governance. Journal of Environmental Policy and Planning. https://doi.org/10.1080/1523908X.2013.769414

[9] Farazmand, A. (2012). Sound Governance: Engaging Citizens through Collaborative Organizations. Public Organization Review. https://doi.org/10.1007/s11115-012-0186-7

[10] Steelman, T. (2016). Adaptive governance. In Handbook on Theories of Governance.

[11] Schultz, L., Folke, C., Österblom, H., \& Olsson, P. (2015). Adaptive governance, ecosystem management, and natural capital. Proceedings of the National Academy of Sciences of the United States of America. https://doi.org/10.1073/pnas.1406493112

[12] Folke, C., Hahn, T., Olsson, P., \& Norberg, J. (2005). Adaptive governance of socialecological systems. In Annual Review of Environment and Resources. https://doi.org/10.1146/annurev.energy.30.050504.144511

[13] Gunderson, L., \& Light, S. S. (2006). Adaptive management and adaptive governance in the everglades ecosystem. Policy Sciences. https://doi.org/10.1007/s11077-006-9027-2

[14] Razaghi, M., \& Finger, M. (2018). Smart Governance for Smart Cities. Proceedings of the IEEE. https://doi.org/10.1109/JPROC.2018.2807784

[15] Pereira, G. V., Parycek, P., Falco, E., \& Kleinhans, R. (2018). Smart governance in the context of smart cities: A literature review. In Information Polity. https://doi.org/10.3233/IP-170067

[16] Vinod Kumar, T. M. (2015). E-Governance for Smart Cities. https://doi.org/10.1007/978-981-287-287-6_1

[17] Simon, H. A., Smithburg, D. W., \& Thompson, V. A. (2017). Public administration. In Public Administration. https://doi.org/10.4324/9781315127705

[18] Dong, L. (2016). Public administration theories: Instrumental and value rationalities. In Public Administration Theories: Instrumental and Value Rationalities. https://doi.org/10.1057/9781137536426

[19] Ansell, C., \& Gash, A. (2008). Collaborative governance in theory and practice. Journal of Public Administration Research and Theory. https://doi.org/10.1093/jopart/mum032

[20] Newman, J., Barnes, M., Sullivan, H., \& Knops, A. (2004). Public participation and collaborative governance. Journal of Social Policy. https://doi.org/10.1017/S0047279403007499

[21] Rasche, A. (2010). Collaborative Governance 2.0. Corporate Governance. https://doi.org/10.1108/14720701011069713

[22] Emerson, K., \& Nabatchi, T. (2015). Collaborative governance regimes. In Collaborative Governance Regimes. https://doi.org/10.1111/padm.12278

[23] Gash, A. (2016). Collaborative governance. In Handbook on Theories of Governance. https://doi.org/10.5840/iabsproc1993412

[24] Ansell, C., \& Gash, A. (2018). Collaborative platforms as a governance strategy. Journal of Public Administration Research and Theory. https://doi.org/10.1093/jopart/mux030 
[25] Binswanger, H. P. (2007). Empowering rural people for their own development. Agricultural Economics. https://doi.org/10.1111/j.1574-0862.2007.00232.x

[26] Boserup, E. (1993). The conditions of agricultural growth: the economics of agrarian change under population pressure. The Conditions of Agricultural Growth: The Economics of Agrarian Change under Population Pressure. https://doi.org/10.2307/142634

[27] Duit, A., Galaz, V., Eckerberg, K., \& Ebbesson, J. (2010). Governance, complexity, and resilience. In Global Environmental Change. https://doi.org/10.1016/j.gloenvcha.2010.04.006

[28] Vinogradoff, P. (1900). Agricultural Services. The Economic Journal. https://doi.org/10.2307/2957216

[29] Zhang, Y. (2003). China's Emerging Civil Society. Comparative and General Pharmacology.

[30] Ahluwalia, M. S. (1976). Inequality, poverty and development. Journal of Development Economics. https://doi.org/10.1016/0304-3878(76)90027-4

[31] Chambers, R. (1995). Poverty and livelihoods: Whose reality counts? Environment \& Urbanization. https://doi.org/10.1177/095624789500700106

[32] Bangura, Y. (2015). Developmental Pathways to Poverty Reduction. In Developmental Pathways to Poverty Reduction. https://doi.org/10.1057/9781137482549

[33] Cheng, Y. (Daniel). (2019). Governing Government-Nonprofit Partnerships: Linking Governance Mechanisms to Collaboration Stages. Public Performance and Management Review. https://doi.org/10.1080/15309576.2018.1489294

[34] Castetbon, K. (2017). Measuring food insecurity. In Sustainable Nutrition in a Changing World. https://doi.org/10.1007/978-3-319-55942-1

[35] Barrett, C. B. (2010). Measuring food insecurity. In Science. https://doi.org/10.1126/science. 1182768

[36] Carletto, C., Zezza, A., \& Banerjee, R. (2013). Towards better measurement of household food security: Harmonizing indicators and the role of household surveys. In Global Food Security. https://doi.org/10.1016/j.gfs.2012.11.006

[37] Sumarto, R. H., Sumartono, Muluk, K. R. K., \& Nuh, M. (2020). Penta-Helix and Quintuple-Helix in the management of tourism villages in Yogyakarta City. Australasian Accounting, Business and Finance Journal. https://doi.org/10.14453/aabfj.v14i1.5

[38] Muluk, K. (2009). Peta Konsep Desentralisasi dan Pemerintah Daerah. In Itpress. https://doi.org/10.1017/CBO9781107415324.004

[39] Korten, D. C. (1987). Third generation NGO strategies: A key to people-centered development. World Development. https://doi.org/10.1016/0305-750X(87)90153-7 